\title{
Managed Trade, Trade liberalisation and Local Pollution
}

Alberto Gallegos* and Pierre Régibeau ${ }^{+}$

J une 17, 2004

- ITESM, Mexico City, ${ }^{+}$University of Essex and CEPR

- Submitting author: Pierre Régibeau, Department of Economics, University of Essex, Wivenhoe Park, Colchester, CO4 3SQ, UK. Tel.: 44-1206872731. Fax: 44-1206 email:pregib@Essex.ac.uk.

- The authors would like to thank C. Montagna and K. Rockett for helpful comments. 


\title{
Managed Trade, Trade liberalisation and Local Pollution
}

\begin{abstract}
The current paper addresses the relationship between trade and endogenous pollution levels. The main focus is quite different from the previous literature. The mechanism linking pollution and trade is that trade provides the home government with a credible threat that helps motivate domestic firms to adopt cleaner technologies. This credible threat comes from the fact that the government has a greater incentive to protect a clean industry than to protect a very polluting one. In that sense, the existence of trade helps reduce domestic pollution compared to what would prevail in a situation of autarky. On the other hand, a commitment to free trade would be counterproductive: it limits the government 's ability to credibly threaten its domestic firms. In fact we show that any trade liberalisation hurts the welfare of the home country. In terms of world welfare, moderate trade liberalisation is helpful but only as long as it does no affect the technology choices of the firms.
\end{abstract}




\section{I ntroduction}

Over the last two decades economists and environmentalists have tried to disentangle the complex linkages between environmental and trade policies to assess the likely effects of free( $r$ ) trade on the environment. The environmentalists ' great fear is that an expansion of international trade might lead to a systematic increase in pollution through an increase in economic activity, the location choices of multinational corporations and/or the weakening of national environmental policies. These concerns are the subject of a large economics literature ${ }^{1}$.

Our paper also addresses the relationship between trade and endogenous pollution levels but we take a different perspective. Rather than ask how more trade is likely to affect the environment, we examine the effects of the type commitment to free( $r$ ) trade that generally emerges from multilateral trade negotiations. We do this in a partial equilibrium model with local pollution. As several of the more polluting industries (e.g. mining, chemicals) are best characterized as oligopolies, models of trade that allow for market power appear especially well-suited to this kind of analysis.

${ }^{1}$ Papers on the topic differ mostly according to whether pollution is strictly local or spills across borders, whether firms are allowed to choose an abatement technology, whether the location of production is endogenous and according to the set of policy tools considered. See Copeland and Taylor (1994 and 2001) and Grossman and Krueger (1991) for seminal contributions in a general equilibrium framework. For partial equilibrium analysis, see Markusen et al. (1995), who examine the location decision of (polluting) firms as well as Conrad (1993), Barret (1994) and Kennedy (1994), where environmental policies are used to affect the international competitiveness of local firms. See Karp et al. (2001) for a recent review of the literature. 
There are many papers on the strategic interaction between oligopolistic firms and governments in an international context. Spencer and Brander (1983), Brander and Spencer(1983) and Eaton and Grossman (1986) show how governments can improve national welfare by committing to trade policies that modify the strategic interaction between firms. In such models, where policies are set before firms make their own choices, governments essentially 'lend' their commitment power to their home firms, helping them to ensure a more advantageous position. This type of models has also been used to discuss how environmental policies can affect the competitiveness of home firms (see Conrad (1993), Barret(1994), Kennedy (1994) and Ulph (1996)). We depart from this traditional approach by assuming that governments have limited commitment power. More precisely we consider, as is traditional, that governments can choose their trade policies before firms choose their output levels but we also allow the firms to choose the type of production technology that they will use before trade policies can be committed to. The main rationale for this is that technology adoption can be argued to be less easily reversible than trade policy choices. In that sense, our timing is similar to the model of Brander and Spencer (1987), where multinational firms choose whether to serve a market through exports or DFI before the host government can commit to levels of trade protection or local taxation.

In our model, the mechanism linking pollution and trade is that trade provides the home government with a credible threat that helps motivate domestic firms to adopt cleaner technologies. ${ }^{2}$ This credible threat comes from the fact that the government has a greater incentive to protect a clean industry than to protect a polluting one. Unless the government controls other perfectly efficient instruments to affect the firms' technological choices, this threat is

\footnotetext{
${ }^{2}$ The basic idea is therefore related to Matsuyama (1990), where the government uses the threat of trade liberalisation to induce efficiency - enhancing investments by domestic firms. However, Matsuyama 's set up is much more complex as the timing of both the government and the firms ' decisions is endogenous.
} 
useful. In that sense, the existence of trade helps reduce domestic pollution compared to what would prevail in a situation of autarky. On the other hand, a commitment to free trade would be counterproductive: it removes the government 's ability to credibly threaten lower levels of protection and decreases, therefore, the domestic firms ' incentives to invest in cleaner production methods.

This basic insight is analysed in the simplest possible two-country partial equilibrium model, presented in section 2 , where we show how 'ex post' trade policy provides incentives to invest in pollution-reducing technologies. The effect of trade liberalisation on home and world welfare is analysed in sections 3 and 4 . Section 5 discusses the robustness of our results and a few extensions. Section 6 concludes.

\section{The Model}

There are two countries, 'Home' and 'Foreign'. Each country has one firm that produces in its country of origin. The home firm is indexed as firm 1, while firm 2 is the foreign firm. These firms sell a homogenous good that can be produced at a constant marginal (and average) cost of $c$, which we will set equal to zero. Two production technologies are available, one clean, one dirty. The dirty technology generates local pollution, while the clean technology does not. The welfare cost of this pollution is proportional to local output, i.e. the social cost pollution at Home is:

$\theta \mathrm{q}_{1}$ if the home firm uses the dirty technology

0 if the home firm adopts the dirty technology 
, where $q_{1}$ is the output of the home firm and $\theta \geq 0$. We assume that the home firm is initially endowed with the dirty technology but can adopt the clean technology at a fixed cost of $F$.

In order to concentrate on the new effect presented in this paper, we assume that the choice of technology does not affect the marginal cost of production. If it did then policies aimed at reducing production would also affect the 'aggressiveness' of the domestic firms. Such well-known 'strategic trade' effects would make computations messier without adding anything new to the analysis.

We will initially focus on the home market where the inverse demand for the homogenous good takes the simplest possible linear form:

$$
P=1-Q
$$

, where $Q=q_{1}+q_{2}$ is total industry output and $P$ is the price in the domestic market. Trade policy takes the form of a unit tariff $t$. We assume that the home country is the only one with an active trade policy ${ }^{3}$.

The benchmark is a situation where the home country is free to set its tariff at any level that it pleases. In such a 'freely managed trade' regime, the timing of the game is as follows. In the first stage the domestic firm must decide whether to keep its current polluting technology or to adopt the new, cleaner, technology. Once the adoption decision is made, the home government chooses the level of its import tariff. There is then a third stage where firms simultaneously choose their levels of output. As discussed in the introduction, the order of the three stages reflects the assumption that the government has

\footnotetext{
${ }^{3}$ See Gallegos (2003) for a discussion of the case with two active governments. As this extension does not add any significant new insight, it is omitted here.
} 
only limited commitment power: while it might be able to commit to a specific level of tariff before firms actually compete in the product market, the choice of tariff is more easily reversible than the firm 's choice of technology. A similar timing can be found in Brander and Spencer (1987) 's analysis of FDI. This game is solved for its unique sub-game perfect equilibrium.

Starting from the managed trade benchmark, we will then consider the effects of 'trade liberalisation', which is modelled as a legally binding upper limit on the level of tariff that the government can choose in stage 2 . We will also consider the extreme case of a commitment to free trade, where the home government completely forgo the use of trade policy. This means that $t=0$ even if the optimal tariff t* were to be negative (which would occur for $\theta>1$ ). In this case, the second stage of the game becomes irrelevant. ${ }^{4}$

The equilibrium quantities of the two firms in the third stage of the game are easily obtained as:

$$
\begin{aligned}
& q_{1}^{*}=\frac{1+t}{3} \\
& q_{2}^{*}=\frac{1-2 t}{3}
\end{aligned}
$$

, where $t$ is the per unit import tariff chosen by the home government in stage 2 . To ensure an interior solution we need $-1<t<1 / 2$. The corresponding tariff revenue is:

$$
T=t q_{2}^{*}=\frac{t(1-2 t)}{3}
$$

\footnotetext{
${ }^{4} \mathrm{~A}$ commitment to free trade is therefore a special case of trade liberalisation, where the upper bound on $\mathrm{t}$ is smaller or equal to $\operatorname{Min}[0,(1-\theta) / 3]$.
} 
The equilibrium profit of the domestic firm, domestic consumer surplus and domestic welfare are:

$$
\begin{gathered}
\pi_{1}^{*}=\frac{(1+t)^{2}}{9} \\
C S=\frac{\left(Q^{*}\right)^{2}}{2}=\frac{(2-t)^{2}}{18} \text { and } \\
W=C S+T+\pi_{1}-\theta q_{1}= \\
\frac{2(1+t)(1-\theta)-3 t^{2}}{6}
\end{gathered}
$$

We can now consider the second stage of the game. Under freely managed trade, the optimal tariff is obtained by maximising $W$ with respect to $t$. This yields:

$$
t *(\theta)=\frac{1-\theta}{3}
$$

In the absence of pollution, this tariff is positive ${ }^{5}$. Crucially for our argument, the tariff is lower, the greater the pollution parameter $\theta$ is. For the domestic firm, this means that adopting a cleaner technology is "rewarded" by stronger ex post protection. As the domestic firm anticipates this reward, the home country 's ability to freely choose its trade policy ex post increases the domestic firm 's incentive to invest in the new technology in stage 1. This is confirmed by substituting the expression for the optimal tariff into the equilibrium profits of the home firm:

\footnotetext{
${ }^{55}$ It is also smaller than $1 / 2$ for all possible values of $\theta$ so that we are sure that the output of the foreign firm will always be positive in equilibrium.
} 


$$
\pi_{1}^{*}=\frac{(4-\theta)^{2}}{81}
$$

The domestic firm 's incentives to invest in the non-polluting technology are therefore given by:

$$
B_{1} \equiv \pi_{1}^{*}(0)-\pi_{1}^{*}(\theta)=\frac{\theta(8-\theta)}{81}
$$

, where $\pi(0)$ is the firm 's profit when it has chosen the clean technology. It is useful to replace $t$ by its optimal value in a number of other variables. We get:

$$
\begin{aligned}
& q_{1}^{*}=\frac{4-\theta}{9} \\
& q_{2}^{*}=\frac{1+2 \theta}{9}
\end{aligned}
$$

so that, to ensure interior solutions, we will assume that $\theta<4$. Notice that, under this assumption, $B_{1}$ is always positive. Hence, the ex post tariff policy that emerges under 'managed trade' provides the domestic firm with greater incentives to invest in the cleaner technology than if the home government had committed to free trade. Under free trade, the domestic firm has no incentive to adopt the less polluting technology: adoption is costly and offers no benefit since the ex post tariff is set equal to zero anyway.

The range of investment costs for which the technology would be adopted under managed trade corresponds to all positive values lower than $B_{1}$. It is shown on figure 1 .

Let us now consider the effect of less extreme trade liberalisation. Define the maximum tariff allowed as $t$. Clearly, liberalisation has no effect if it is not binding, i.e. if $\bar{t} \geq t^{*}(\theta=0)=\frac{1}{3}$. On the other hand, any trade liberalisation that lowers the maximum allowed tariff below $1 / 3$ will decrease the domestic firm 's 
incentive to adopt the clean technology. For $\bar{t} \in\left[\max \left(0, \frac{1-\theta}{3}\right), \frac{1}{3}\right]$, liberalisation reduces the protection granted after adoption while it leaves the protection level without adoption unchanged. If pollution is not too intense (i.e. $\theta<1$ ), there is a further range of liberalisation where $\bar{t} \in\left[0, \frac{1-\theta}{3}\right]$, for which all incentives to switch to the cleaner technology are eliminated. We can therefore state the following proposition:

Proposition 1: Any binding trade liberalisation lowers the domestic firm 's incentives to invest in cleaner technology. In particular, incentives to invest in cleaner technology are higher under managed trade than under free trade.

\section{Home Country 's Welfare}

The fact that private incentives to choose cleaner technologies are enhanced by managed trade does not of course guarantee that these technological choices are optimal from the point of view of the home country. To compare private and social incentives to adopt the cleaner technology we must compare $B_{1}$ to the change in the home country ' $s$ welfare that is triggered by a move to the new technology. This change is given by:

$$
\Delta W=\Delta C S^{*}+\Delta T^{*}+\Delta \pi_{1}^{*}-F+\theta q_{1}^{*}(\theta)
$$

, where $\Delta \mathrm{x}$ refers to the difference between the value of $\mathrm{x}$ when the clean technology is adopted - and the tariff set accordingly - and the value of $x$ when the firm chooses to use the dirty technology The first term represents the effect on consumer surplus. This is unambiguously negative as the adoption of a cleaner technology leads to greater levels of protection and, therefore, a higher 
domestic price. The last term corresponds to the decrease in pollution levels and is therefore positive. The third term represents the firm 's private incentives to adopt the cleaner technology (i.e. it is equal to $B_{1}$ ). As we have just seen, this is positive. Anyway, as $\Delta \pi-F$ is fully taken into account by the domestic firm, these terms do not affect a comparison of private and social incentives. Finally, the change in tariff revenues can a priori be either positive or negative.

Our interest lies in the difference between $\Delta \mathrm{W}$ and $\mathrm{B}_{1}$ :

$$
\Delta W-\left(B_{1}-F\right)=\Delta C S^{*}+\Delta T^{*}+\theta q_{1}^{*}(\theta)=\frac{7 \theta}{162}[8-\theta]
$$

, which is positive for all relevant values of the pollution parameter (i.e. $\theta<4$ ), and negative for high values of $\theta$. This means that there are values of $F$ for which adoption of the clean technology is desirable but does not happen but there are no values of $\mathrm{F}$ for which socially undesirable adoption is observed. This is shown in Figure 2 and summarised in proposition 2.

Proposition 2: Freely managed trade provides incentives for the adoption of the clean technology but these incentives are insufficient from the point of view of the home country overall welfare

This result immediately suggests that managed trade always yields higher domestic welfare than free trade or, indeed than any binding level of trade liberalisation (i.e. $\bar{t}<\frac{1}{3}$ ).

If trade liberalisation does not change the adoption behaviour of the domestic firm then it cannot increase the home country 's welfare. If the 
domestic firm invests in the clean technology anyway, any value of $\bar{t}$ below $\frac{1}{3}$ simply prevents the domestic government from setting its ex post optimal tariff. If the home firm sticks with the dirty technology anyway then any $\bar{t}$ above $\frac{1-\theta}{3}$ does not affect welfare since the ex post optimal tariff can still be chosen. On the other hand, further liberalisation bringing $\bar{t}$ below $\frac{1-\theta}{3}$, would force the country to set a sub-optimal tariff ex post, lowering its welfare.

Let us now consider a level of trade liberalisation that would change the technology choice of the domestic firm. From proposition 1 we know that trade liberalisation cannot increase the firm 's incentives to adopt the clean technology. Hence we only have to analyse the case where the firm would adopt under freely managed trade but would not after trade has been liberalised. Define the level of tariff below which the firm ceases to invest in the clean technology as $\bar{t}_{\mathrm{c}}$. Consider a trade liberalisation such that $\bar{t}<\bar{t}_{\mathrm{c}}$. Since the firm already has insufficient incentives to invest, such liberalisation can only be welfare decreasing: the country reacts to any tariff bound just below the critical level $\bar{t}_{\mathrm{c}}$ by choosing its optimal 'no adoption' ex post tariff $t=\frac{1-\theta}{3}$. As $\Delta W-B_{1}>0$, we know that this yield a level of welfare that is lower than when the country can induce adoption and set its ex post tariff equal to $\frac{1}{3}$. Hence we can state:

Proposition 3: Trade liberalisation can never increase domestic welfare.

The evolution of domestic welfare as the upper bound on tariff is tightened is summarised in figure 3. Figure 3.a. corresponds to an initial situation of insufficient adoption (region A in figure 2). As explained above, 
trade liberalisation has no effect on the home country 's welfare until the maximum tariff reaches $\frac{1-\theta}{3}$. Further liberalisation beyond this point decreases welfare. Figure $3 b$ is drawn for an initial point in region B of figure 2. As soon as liberalisation becomes binding, it decreases home welfare. This decrease continues up to the point where the firm no longer adopts the clean technology. At this point, welfare can in principle jump up or down. This depends on whether welfare without adoption and an optimal ex post tariff of $\frac{1-\theta}{3}$ is higher or lower than welfare with adoption an a constrained tariff equal to $\bar{t}_{c}$. If welfare jumps up, we still know that it remains lower than without trade liberalisation: in region $B$ adoption with an unconstrained tariff is better than no adoption with an unconstrained tariff. Further liberalisation does not affect welfare until $\bar{t}$ reaches $\frac{1-\theta}{3}$, at which point further decreases in $\bar{t}$ are welfare - decreasing.

While we have focused on the issue of trade liberalisation, it should be clear that, in our model, autarky is never optimal either. To see this, notice that autarky, just like trade with $\bar{t} \leq \bar{t}_{\mathrm{c}}$, never induces adoption of the clean technology. If there is no adoption, the home country does best by setting its ex post optimal tariff of $\frac{1-\theta}{3}$. As this tariff is not prohibitive, it must, by definition, yield higher home welfare than autarky. Hence, some amount of trade liberalisation is always preferable to autarky. A similar argument holds when adoption would occur under freely managed trade and would be socially optimal (region $B$ in figure 2): if managed trade is better than the best possible regime without adoption and adoption is desirable than managed trade must be better than autarky. 
Proposition 4: There always exists a degree of trade liberalisation for which the home country 's welfare is greater than under autarky. Autarky is also dominated by freely managed trade.

\section{World Welfare}

World welfare differs from the home country 's welfare in two respects: it includes the profits of the foreign firm as well as the pollution associated with foreign production. Because of this second term, we cannot evaluate world welfare without making some assumption about the technology used by the foreign firm. In the first part of this section, we will simply assume that the foreign firm is using the clean technology so that foreign pollution is not an issue. In the second part we will look at the opposite case where the foreign firm uses the dirty technology so that foreign pollution further complicates the analysis

\section{a. 'Clean' Foreign Firm}

Adoption of the clean technology by the home firm leads to higher tariff levels ex post, thereby reducing the equilibrium profits of the foreign firm. Since these profits are the difference between world welfare and home welfare, adoption must be less desirable from the world point of view than from the viewpoint of the home country alone. We cannot therefore a priori rule out that there might be values of the parameters for which the domestic firm 's private decision to adopt the clean technology might actually reduce world welfare. World welfare is given by:

$$
W^{w}=P^{*} Q^{*}-\theta q_{1}^{*}=\frac{(4-\theta)(5-8 \theta)}{81}
$$


This means that, from the point of view of the world as a whole, adoption of the clean technology by the home firm is desirable if and only if:

$$
\Delta W^{w}=\frac{20}{81}-\frac{(4-\theta)(5-8 \theta)}{81}-F=\frac{\theta(37-8 \theta)}{81}-F \geq 0
$$

Comparing this to the private adoption incentives of he home firm we have:

$$
\Delta W^{w}-B_{1}=\frac{\theta(29-7 \theta)}{81}
$$

Since this expression is positive for all $\theta \leq 4$, the firm' $s$ incentives to adopt cannot in fact ever be excessive from the point of view of world welfare.

\section{b. 'Dirty' Foreign Firm}

If the foreign firm relies on a dirty technology, then adoption of the clean technology by the home firm has an additional positive effect on world welfare. Adoption results in higher tariffs. These higher tariffs reduce the output of the foreign firm and the corresponding foreign pollution. Since incentives to adopt were already insufficient in the presence of a 'clean' foreign firm, they still are when the foreign firm itself contributes to overall pollution.

Proposition 5: Freely managed trade provides incentives for the adoption of the clean technology but these incentives are insufficient from the point of view of the worldl welfare

The qualitative effect of trade liberalisation on world welfare does not depend on whether or not the foreign firm pollutes. The general pattern is shown in figure 5 . To the right of the critical tariff level $\bar{t}_{c}$, the clean technology 
is adopted. For all $\bar{t} \in\left[\bar{t}_{c}, \frac{1}{3}[\right.$, the home country will set the maximum tariff allowed. Hence world welfare decreases as $\bar{t}$ increases. For $\bar{t} \geq \frac{1}{3}$, the home country chooses its ex post optimal tariff and world welfare remains constant. To the left of the critical tariff, the domestic firm sticks to its dirty technology. For all values of $\bar{t}$ between $\frac{1-\theta}{3}$ and $\bar{t}_{c}$, the home country chooses the ex post optimal tariff $t=\frac{1-\theta}{3}$ and world welfare is constant over this range. As further liberalisation decreases the level of tariffs without further affecting technology choice, it also increases world welfare.

We must still discuss the relative 'height' of the different segments of the welfare function in figure 4 . We know that, whenever adoption happens and the home country 's optimal ex post tariff is chosen, world welfare is higher than when the clean technology is not adopted and the home country chooses its ex post optimal tariff. This means that the horizontal segment to the right of $\bar{t}_{c}$ must lie higher than the horizontal segment to the left. On the other hand, the relative position of the rightmost horizontal segment and the level of welfare under free trade is not a priori clear. Welfare under free trade is:

$$
W_{f}^{w}\left(\theta_{2}=0\right)=\frac{2-3 \theta}{9}
$$

if the foreign firm does not pollute and

$$
W_{f}^{w}\left(\theta_{2}=\theta\right)=\frac{2(1-3 \theta)}{9}
$$

if it does. The corresponding levels of welfare under freely managed trade are 


$$
W_{m}^{w}\left(\theta_{2}=0\right)=\frac{20}{9}-F
$$

with a clean foreign firm and

$$
\frac{20-\theta}{9}-F
$$

with a dirty one.

It is straightforward to show that, irrespective of the foreign firm 's technology, $W_{m}^{w}-W_{f}^{w}+F>B_{1}$, i.e. the cost of investment $F$ which is just large enough to make free trade as attractive as freely managed trade is larger than the maximum cost investment that the home firm is willing to shouldered. This implies that world welfare under freely managed trade must be larger than under free trade. Moreover, figure 4 clearly shows that welfare is maximised at $\bar{t}=\bar{t}_{c}$. Hence we can state:

Proposition 6: World welfare is higher under freely managed trade than under free trade. Still a moderate trade liberalisation that constrains the home country tariff without preventing the adoption of the clean technology by the home firm improves world welfare.

\section{Robustness}

In this section we briefly discuss the robustness of our results to four kinds of extensions: more firms, more general demands, other models of oligopoly and the availability of other policy instruments. 


\section{a. More Firms, More General Demands and Other Models of Oligopoly}

The conclusion that the domestic firms ' incentives to adopt the clean technology are larger under freely managed trade than under free trade (or partial liberalisation) holds under quite general conditions. Define $\theta_{i}$ as firm i 's pollution parameter. Firm i 's incentives to clean up its technology is determined by:

$$
\frac{d \pi_{i}}{d \theta_{i}}=\frac{d \pi_{i}}{d t} \frac{d t *}{d \theta_{i}}
$$

reflecting the fact that firm i 's technological choice only affects its profits through its effect on the ex post optimal tariff. As we can see, our main result depends on two effects.

Firstly we need an increase in the cleanliness of a firm 's technology to result in a higher ex post tariff (i.e. $d t^{*} / d \theta_{l}<0$ ). Let us write the country 's welfare as

$$
W=C S(t)+t n^{*} q^{*}(t)+n \pi(t)-\theta_{i} q_{i}(t)-\sum_{j \neq i}^{n} \theta_{j} q_{j}(t)
$$

, where $n *$ is the number of foreign firm, $n$ is the number of domestic firm and $\theta_{i}$ is the degree of dirtiness of firm I 's technology. The value of t* is therefore determined by

$$
\frac{d W}{d t}=C S(t)+n^{*} q^{*}(t)+t n^{*} q^{* \prime}(t)+n \pi^{\prime}(t)-\theta_{i} q_{i}^{\prime}(t)-\sum_{j \neq i}^{n} \theta_{j} q_{j}{ }^{\prime}(t)
$$

Hence,

$$
\frac{d t^{*}}{d \theta_{i}}=-\frac{-q_{i}{ }^{\prime}(t)}{\frac{d^{2} W}{d t^{2}}}
$$


, which is negative in for all models of oligopoly where a firm 's output expands when some of its rivals are hit by a per unit tax. ${ }^{6}$

The second effect that we need in order to reach our conclusion is simply that the domestic firm benefits from a higher tariff (i.e. $d \pi_{i} / d t^{*}>0$ ). As a tariff just shifts the residual demand of the domestic industry out, this effect arises in every common model of oligopolistic competition.

The precise welfare results that we obtain are much less robust. They might well change if different functional forms were used. Crucially we cannot be certain that the domestic firm 's incentives to adopt the new technology will always fall short of the associated benefits for its home country or for the world as a whole. If they did not, then there would be a range of parameters for which adoption would occur even though it would not be welfare maximising. In such a case one can show that trade liberalisation that is drastic enough to discourage adoption would in fact increase welfare. Moreover such a 'drastic' level of trade liberalisation would always exist. This argument is sketched briefly below.

Suppose that, with different functional forms, we obtained a range of parameters for which the domestic firm would adopt the clean technology even though home welfare would be higher if it stuck with the dirty technology. The effect of trade liberalisation on the welfare of the home country could then be

\footnotetext{
${ }^{6}$ This will be true in most of the oligopoly models used in trade theory. In any model of quantity competition with downward sloping reaction functions, the tariff shifts the reaction functions of foreign firms in, resulting in larger equilibrium output for all (symmetric) domestic firms. In a model of price competition with differentiated products and upward sloping reaction functions, the tariff shifts the reaction functions of the foreign firms out. This results in higher equilibrium prices for all firms but the prices of domestic firm increases less than the prices of foreign firm. Using stability conditions, one can show that the output of each (symmetric) domestic firm actually increases (see Vives (1999).
} 
represented in the following graph. The graph is very similar to figure $3 \mathrm{~b}$. So is the reasoning involved.

Starting from unrestricted managed trade, a progressive tightening of $\bar{t}$, leaves home welfare unchanged until it reaches the ex post optimal tariff given that the cleaner technology has been adopted, defined as $t_{n}$ * (i.e. $\frac{1}{3}$ in our linear demand example). For $\bar{t}$ between $\bar{t}_{c}$ and $t_{n} *$, adoption still takes place but the home country cannot set its preferred tariff ex post. Hence home welfare decreases. As in figure $4 \mathrm{~b}$. trade liberalisation that moves $\bar{t}$ below $\bar{t}_{c}$ prevents the adoption of the new technology. Since technology adoption was undesirable even if the tariff could be set at $t_{n}{ }^{*}$, avoiding adoption when the tariff is capped below $t_{n} *$ must increase domestic welfare. Moreover, domestic welfare must jump to a level that is higher than when $\bar{t} \geq \mathrm{t}_{\mathrm{n}}{ }^{*}$. Domestic welfare remains at this level as long as $\bar{t}$ remains higher than the ex post optimal tariff in the absence of adoption, defined as $t_{0}^{*}$ (equal to $\frac{1-\theta}{3}$ in our linear example). Tightening the tariff cap beyond this level is again welfare decreasing. Overall then, the home country 's welfare is maximised by committing to a tariff cap that lies between $\mathrm{t}_{0}{ }^{*}$ and $\bar{t}_{c}$. We can then conclude that when freely managed trade results in undesirable adoption of the new technology, moderate trade liberalisation - sufficient to prevent adoption but leaving the country free to set its ex post optimal tariff - unambiguously increases the home country 's welfare.

Essentially, trade liberalisation helps the home country credibly commit not to 'reward' the home firm for the adoption of the new technology. As incentives to adopt disappear at a tariff rate that is above the ex post optimal tariff rate without adoption, a suitable tariff cap can eliminate undesirable 
adoption without affecting the level of domestic welfare in the non-adoption outcome.

\section{b. Other Instruments}

As presented, the analysis is obviously vulnerable to the introduction of other policy instruments. In fact, a government who could commit to paying a lump sum subsidy $\mathrm{S}$ to domestic firms adopting the clean technology and who could finance this costlessly would always be able to induce adoption of the clean technology whenever this is socially desirable. On the other hand, unless lump sum taxes on pollution-reducing investments were also contemplated (this seems politically difficult), the government would not be able to avoid excessive adoption. In that case, as we have just seen, trade liberalisation would remain useful.

More importantly, subsidies cannot usually be financed costlessly. If one assumes that each unit of subsidy involves a social cost of $(1+\lambda)$, with $\lambda \geq 0$, then our analysis remains quite relevant. As the subsidy is now costly, the government will choose the smallest possible subsidy that induces the desirable adoption behaviour. Hence the optimal size of the subsidy depends precisely on the type of analysis that we have conducted. Referring to figure 2, any parameter combination in region $B$ would call for $S=0$. As the change in the ex post optimal tariff suffices to induce the (desirable) adoption of the clean technology and the ex post optimal tariff $t_{n}^{*}=\frac{1}{3}$ will be imposed whether or not subsidies are given, using subsidies would be a waste of resources. For any combination of parameters in region $A$, the only sensible subsidy is one that is just sufficient to induce adoption given the reward that will be granted anyway through the optimal post-adoption increase in tariff, i.e. $\mathrm{S}=\mathrm{F}-\mathrm{B}_{1}$. If $\lambda$ is small 
enough than this subsidy should indeed be used. For $\lambda$ large enough the home country is better off relying exclusively on the ex post tariff mechanism that we have analysed.

\section{Conclusion}

The main point of this paper is very simple. In the presence of local pollution, a home government will protect its industry from foreign competition more if its domestic firms use a clean production technology. The anticipation of this ex post optimal trade policy gives domestic firms incentives to adopt clean(er) technologies in the first place. The ability to set an unconstrained tariff ex post is therefore valuable as an instrument to foster pollution-reducing investments. Countries that enter binding agreements limiting their ability to set tariffs might therefore lose a valuable tool to protect their environment. In that sense, a commitment to free trade can hurt the environment.

Whether the use of ex post tariffs provides adequate incentives for the adoption of cleaner technologies is less clear. With linear demand and Cournot duopoly, we show that the incentives provided are in fact insufficient. It follows that a commitment to trade liberalisation never increases domestic (or world) welfare. In fact, trade liberalisation that is drastic enough unambiguously decreases the welfare of the home country. In a more general setting, one cannot rule out the possibility that ex post tariffs provide domestic firms with excessive incentives to clean up their act. In such a case moderate trade liberalisation increases the country 's welfare. 


\section{References}

Barret, S., 1994, "Strategic Environmental Policies and International Trade", Journal of Public Economics, 54, pp. 325 - 338.

Brander, J. and B. Spencer, 1985, "Export Subsidies and Market Rivalry", 1985, Journal of International Economics, 18, pp. 83-100

Brander, J. and B. Spencer, 1987, "Foreign Direct Investment with Unemployment and Endogenous Taxes and Tariffs", Journal of International Economics, 22, pp. 257-279

Conrad, K., 1993, "Taxes and Subsidies for Pollution-I ntensive Industries as a Trade Policy", Journal of Environmental Economics and Management, 25, pp. $121-135$.

Copeland, B.R. and M.S. Taylor, 1994, "North-South Trade and the Environment" Quarterly Journal of Economics, 109, pp. 755-787.

Copeland, B.R. and M.S. Taylor, 2001, "International Trade and the Environment: A Framework for Analysis", NBER Working Paper No 8540.

Eaton, J. and G. Grossman, 1986, “Optimal Trade and Industrial Policy under Oligopoly", Quarterly Journal of Economics, 101, pp. 383-406.

Gallegos, A., 2004, International Trade and Environmental Protection, Ph.D Thesis, University of Essex, February 2004

Grossman, G.M. and A.B. Krueger, 1995, "Economic Growth and the 
Environment", Quarterly Journal of Economics, 110, pp. 353 - 377.

Karp, L., S. Sacheti and J. Zhao, 2001, "Common Ground Between Free Traders and Environmentalists", International Economic Review, 42.3, pp. $617-647$.

Kennedy, P. W., !994, "Equilibrium Pollution Taxes in Open Economies with Imperfect Competition", Journal of Environmental Economics and Management, 27, pp. 49 - 63.

Markusen, J.R., E.R. Morey and N.D. Olewiler, 1995, "Competition in Regional Environment Policies when Plant Locations are Endogenous", Journal Of Public Economics, 56, pp. 55 - 77.

Matsuyama, K., 1990, "Perfect Equilibria in a Trade Liberalization Game", American Economic Review, 80 (3), pp. 480 - 492.

Ulph, A., 1996, "Environmental Policy and International Trade when Governments and Producers Act Strategically", Journal of Environmental Economics and Management, 30, pp. 265 - 281.

Vives, X., 1999, Oligopoly Pricing :Old Ideas and New Tools, MIT Press, Cambridge, Mass. 


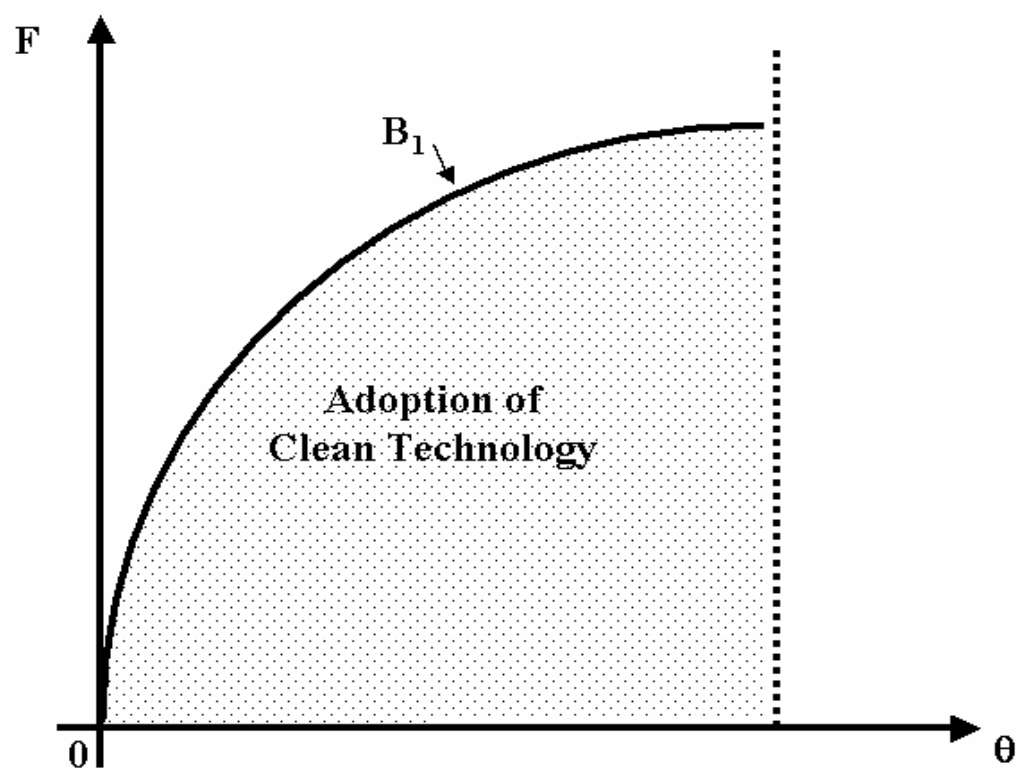

Figure 1: Private Incentives to Adopt the Clean Technology

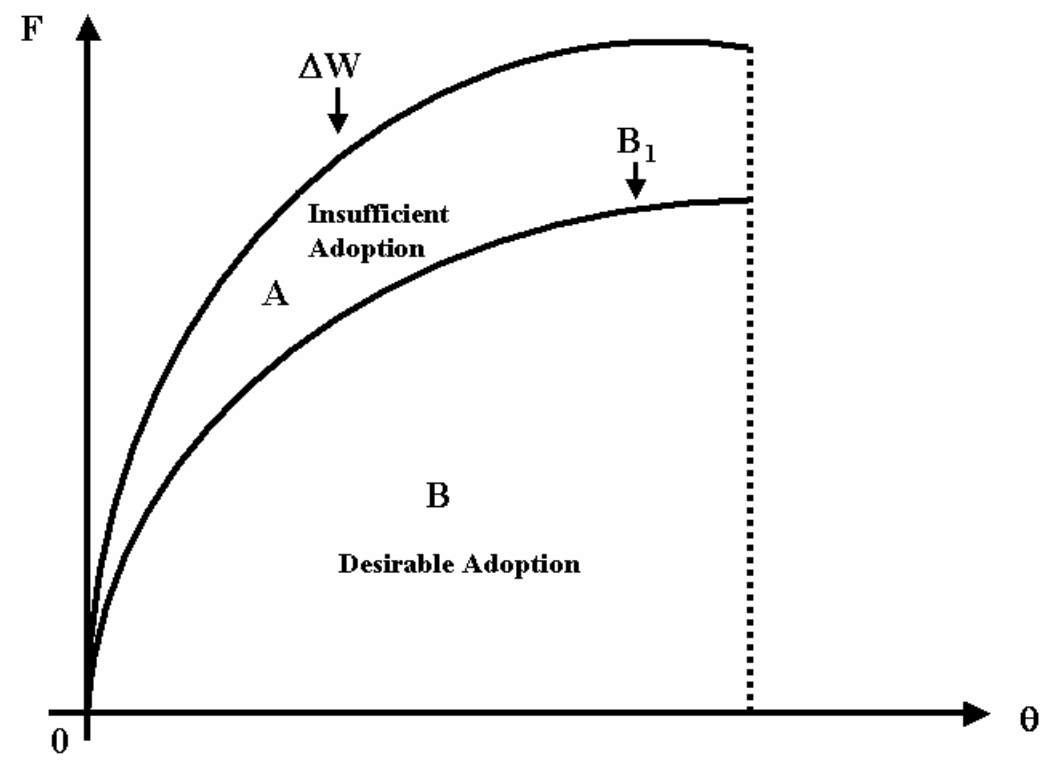

Figure 2: Private I ncentives to Adopt and Home Country Welfare 


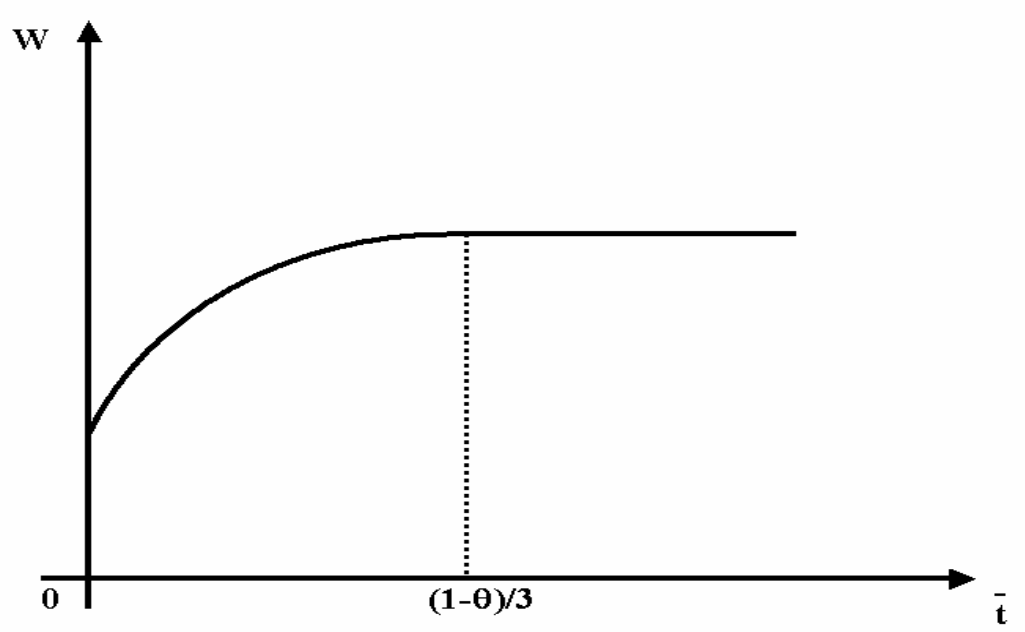

Figure 3.a.

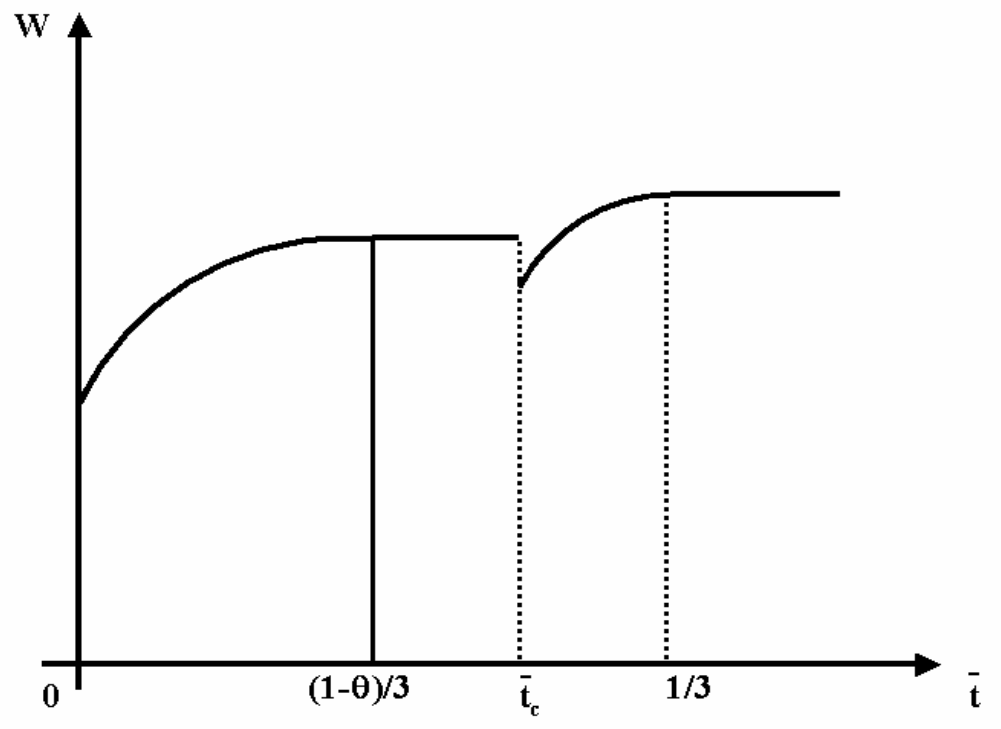

Figure $3 b$. 


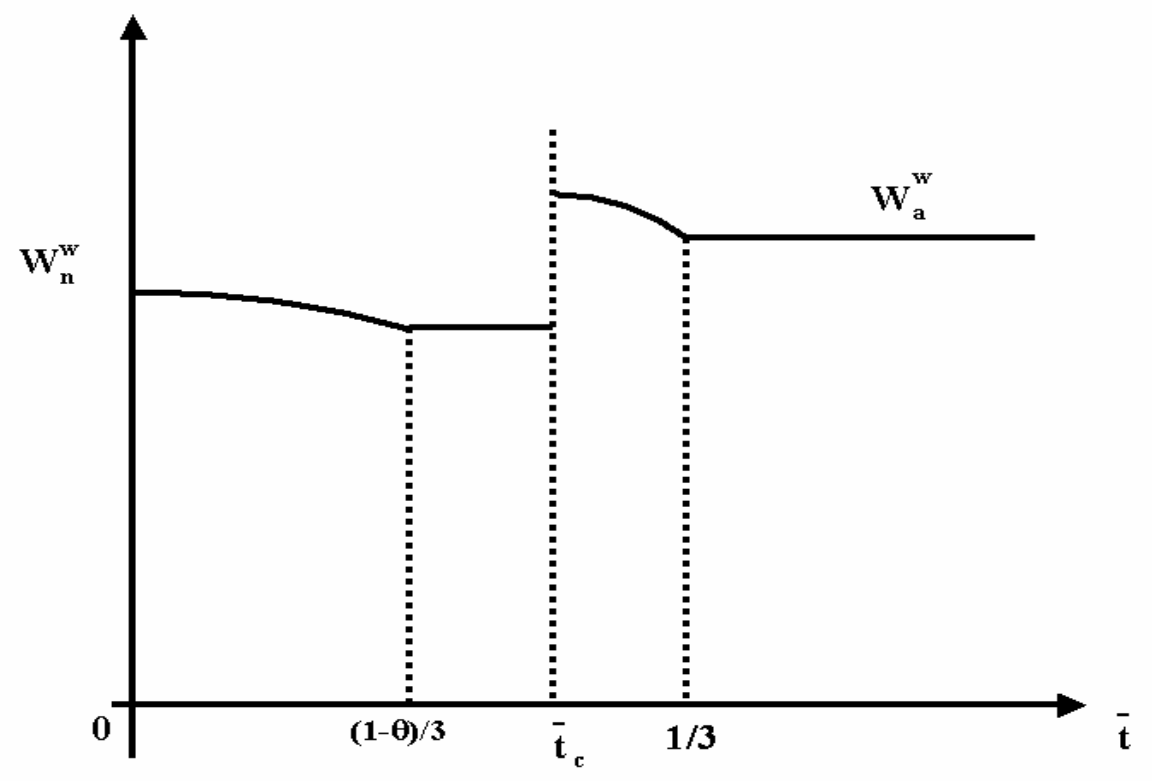

Figure 4: Trade Liberalisation and World Welfare

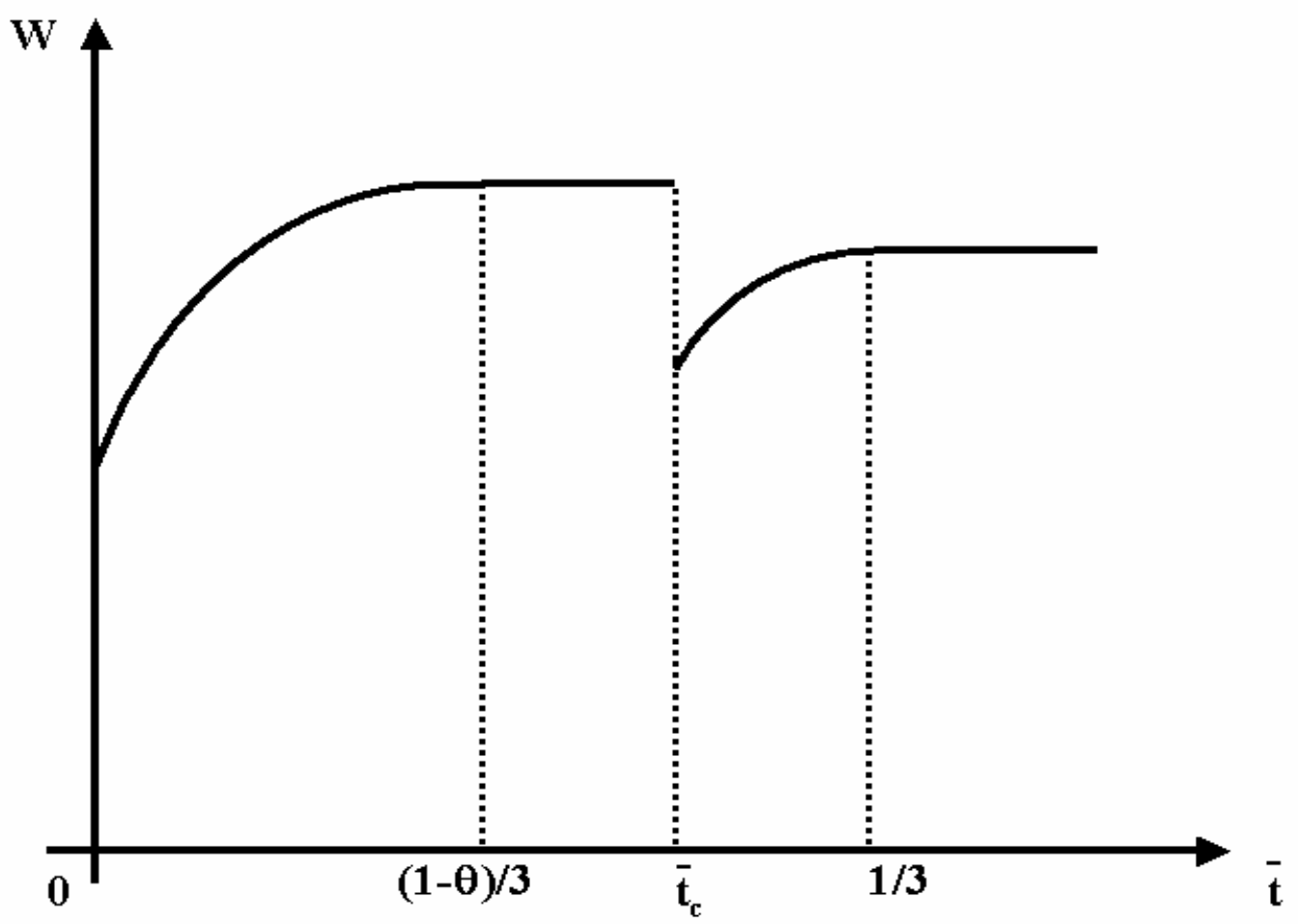

FIGURE 5 